\title{
ANALISIS PENERAPAN VARIABEL COSTING SEBAGAI ALAT UNTUK MENGHITUNG HARGA POKOK PRODUKSI PADA AKSAN BAKERY DI MANADO
}

\author{
Tety Darise \\ David Paul Elia Saerang \\ Anneke Wangkar
}

\section{Fakultas Ekonomi dan Bisnis, Jurusan Akuntansi Universitas Sam Ratulangi Manado}

Email : tety.darise@gmail.com

\begin{abstract}
Determining the cost of goods sold is right becomes one factor supporting the success of a company in achieving its goals, the cost of production has an important role in a company, due to the determination of the cost of goods sold, the company could easily determine the selling price, and the targeted profit also clear. This research was conducted at a company manufacturing in Manado. This study aimed to analyze the application of variable costing in Aksan Bakery in Manado. Data analysis method used is descriptive analysis . The data used is qualitative data, the data is presented in a descriptive or shape description and quantitative data, the data presented in the form of numbers. The research findings show that the application of variable costing method can be used as a tool to calculate the cost of production in the Aksan Bakery. It can be seen from a comparative analysis of the cost of goods sold according to variable costing lower than the production cost price calculation method used Aksan Bakery. By using the full costing method used by companies the cost of goods sold $\mathrm{Rp}$. 1.191.956 .000 while according to the variable cost of production costing Rp . 1.033.560.000. The main difference between full costing calculation method used by the company with variable costing method lies in the treatment of factory overhead costs .
\end{abstract}

Keywords : cost of goods sold, variabel costing 


\section{PENDAHULUAN}

\section{Latar Belakang}

Perkembangan perekonomian Indonesia saat ini secara tidak langsung telah mendorong semakin ketatnya persaingan antar perusahaan diberbagai bidang. Untuk itu perusahaan memerlukan data yang relevan dan siap pakai agar dapat mengambil keputusan dengan tepat dan segera. Sebab keterlambatan dalam mengambil keputusan dapat berarti kerugian bagi perusahaan. Dan hal ini berarti akan sulit bagi perusahaan untuk dapat mempertahankan kelangsungan hidupnya serta berperan dalam pengembalian di masa yang akan datang (Olivia Reppie, 2013: 1061).

Perusahaan merupakan organisasi yang mempunyai berbagai tujuan baik jangka panjang maupun jangka pendek, salah satu tujuan yang penting bagi perusahaan yaitu pencapaian laba optimum. Pencapaian laba dirasa penting karena berkaitan dengan berbagai konsep akuntansi antara lain kesinambungan perusahaan dan perluasan perusahaan. Biaya produksi merupakan unsur dari harga pokok produksi yang merupakan salah satu bagian terpenting dalam menentukan harga jual terutama bagi perusahaan industri. Oleh karena itu, harga pokok produksi merupakan elemen penting untuk menilai keberhasilan dari perusahaan.

Harga pokok produksi biasanya terdiri dari dua jenis biaya yaitu biaya produksi dan biaya non produksi, dalam penentuan harga pokok produksi harus diperhatikan unsur-unsur biaya apa saja yang masuk dalam harga pokok produk dan mengalokasikan unsur-unsur biaya tersebut secara tepat sehingga dapat menggambarkan pengorbanan sumber ekonomi yang sesungguhnya (IndroDjumali, 2014: 83). Biaya produksi akan membentuk harga pokok produksi yang digunakan untuk menghitung harga pokok produk jadi, sedangkan biaya non produksi akan ditambahkan pada harga pokok produksi untuk menghitung total harga pokok produk. Informasi dan pengumpulan biaya produksi yang tepat akan sangat menentukan perhitungan harga pokok produksi yang tepat pula.

Harga pokok produksi mempunyai kaitan erat dengan indikator-indikator tentang kesuksesan sebuah perusahaan, misalnya laba kotor penjualan dan laba bersih. Maka dari itu perusahaan harus memperhatikan harga pokok produksi untuk efisiensi biaya yang dikeluarkan oleh perusahaan. Penentuan harga pokok produksi yang tepat menjadi salah satu faktor penunjang suksesnya sebuah perusahaan dalam mencapai tujuannya, harga pokok produksi memiliki peran penting dalam sebuah perusahaan, karena dengan adanya penentuan harga pokok produksi maka perusahaan bisa dengan mudah menentukan harga jual produk, dan laba yang ditargetkan juga jelas.

Metode variabel costing adalah metode untuk menentukan harga pokok produk dengan hanya memperhitungkan biaya produksi variabel saja, biaya-biaya yang diperhitungkan sebagai harga pokok produksi dalam metode variabel costing adalah biaya produksi variable yang terdiri dari biaya bahan bakulangsung, biaya tenaga kerja langsung, dan biaya overhead pabrik variable. Dalam pendekatan variabel costing, hanya biaya-biaya produksi yang berubah sejalan dengan perubahan output yang diperlakukan sebagai elemen harga pokok produk.

Aksan bakery merupakan perusahaan yang bergerak dibidang produksi roti, perusahaan ini dimana dalam menjalankan aktivitas usahanya senantiasa mengalami peningkatan, dengan makin banyaknya permintaan konsumen terhadap produk roti yang diproduksi oleh Aksan Bakery. Seiring dengan penigkatan tersebut maka masalah yang timbul dalam perusahaan juga semakin rumit, dengan penggunaan biaya produksi yang terus meningkat, maka perhitungan harga pokok produksi menjadi semakin penting. Oleh karena itu perlu dilakukan evaluasi tentang penggunaan biaya-biaya dalam kegiatan produksi. Kesalahan dalam perhitungan harga pokok produksi menjadi penyebab adanya pembebanan biaya yang tidak relevan, yang berdampak pada harga pokok produksi yang meningkat, sehingga mempengaruhi harga jual produk dipasaran. Mengingat umur perusahaan ini yang masih dini maka alangkah baiknya pemilik perusahaan lebih bijak lagi dalam menerapkan metode untuk menentukan harga pokok produksi, demi kelangsungan perusahaan, serta profit perusahaan. 


\section{Tujuan Penelitian}

Untuk menganalisis penerapan metode variabel costing sebagai alat untuk menghitung harga pokok produksi pada Aksan Bakery di Manado, dan membandingkannya dengan metode yang dipakai perusahaan dalam menghitung atau menetapkan harga pokok produksi.

\section{TINJAUAN PUSTAKA}

\section{Akuntansi}

Menurut Arfan (2012: 2) menyatakan bahwa Akuntansi dapat dipandang sebagai suatu proses atau kegiatan yang meliputi proses pengidentifikasian, pengukuran, pencatatan, pengklasifikasian, penguraian, penggabungan, pengiktisaran dan penyajian data keuangan yang terjadi sebagai akibat dari kegiatan operasi suatu unit organisasi. akuntansi merupakan kegiatan mengidentifikasi, mencatat, menggolongkan, mengikhtisarkan transaksi-transaksi keuangan yang bertujuan untuk menyajikan informasi keuangan dalam kegiatan perusahaan. Dimana Informasi tersebut dapat digunakan sebagai bahan pengambilan keputusan atau memilih alternatif ekonomi dan tanggung jawab dibidang keuangan.

\section{Akuntansi Manajemen}

Menurut Hurriyah (2015: 12) Akuntansi manajemen merupakan bidang akuntansi yang menggunakan baik data historis maupun data-data taksiran dalam membantu manajemen untuk merencanakan operasioperasi dimasa yang akan datang. Menurut (Bake : 2010) Akuntansi manajemen adalah aplikasi praktis dari teknik manajemen untuk mengontrol dan melaporkan pada sumber daya keuangan badan usaha, ini melibatkan analisis perencanaan, implementasi, dan pengendalian program yang dirancang untuk memberikanpelaporan keuangan untuk mengambil keputusan. akuntansi manajemen adalah salah satu dari bagian akuntansi yang dipakai oleh manajemen perusahaan untuk perencanaan, pengendalian, dan pengambilan keputusan.

\section{Akuntansi Biaya}

Akuntansi biaya merupakan bidang akuntansi yang mencatat, mengukur, dan melaporkan informasi tentang besarnya biaya dalam bentuk laporan biaya (Marwanto, 2011: 1988). Menurut Samryn (2012: 12) Akuntansi biaya merupakan proses penentuan biaya produk atau kegiatan, data biaya dapat digunakan baik untuk laporan internal maupun laporan eksternal. akuntansi biaya merupakan salah satu dari bagian akuntansi yang aktivitas utamanya meliputi perencanaan, pencatatan, pengendalian, dan pelaporan akan aktivitas perusahaan yang berhubungan dengan keuangan perusahaan.

\section{Pengertian Biaya}

Definisi biaya menurut Slamet Sugiri (2015: 20) Biaya merupakan semua pengorbanan yang secara langsung ataupun tidak langsung dikeluarkan untuk melakukan kegiatan tertentu, misalnya kegiatan produksi atau membeli aset tetap. Biaya adalah suatu pengorbanan ekonomis untuk memperoleh atau memproduksi barang dan jasa yang bemanfaat pada masa sekarang dan masa yang akan datang.

\section{Klasifikasi Biaya}

Klasifikasi biaya bertujuan untuk menyajikan informasi biaya yang digunakan untuk berbagai tujuan, sehingga penggolongan biaya juga disesuaikan dengan tujuan tersebut. Ada beberapa cara yang dapat digunakan untuk menggolongkan biaya diantaranya :

1. Berdasarkan fungsi pokok dalam perusahaan

2. Berdasarkan hubungannya dengan sesuatu yang dibiayai

3. Berdasarkan hubungannya dengan volume kegiatan

4. Berdasarkan jangka waktu manfaatnya

\section{Pengertian Biaya Produksi}

Biaya produksi adalah sejumlah pengorbanan ekonomis yang harus dikorbankan untuk memproduksi suatu barang. Biaya produksi juga merupakan biaya yang digunakan dalam mengubah bahan baku menjadi 
barang jadi. Biaya produksi ini biasanya terdiri dari tiga unsur yaitu bahan baku langsung, tenaga kerja langsung dan overhead pabrik (Christy Oentoe : 2013). Biaya produksi adalah biaya yang berhubungan langsung dengan kegiatan operasional perusahaan yang terdiri dari biaya bahan baku, biaya tenaga kerja, dan biaya overhead pabrik. Biaya produksi juga perlu diklasifikasikan menurut jenis atau objek pengeluarannya, hal ini penting agar pengumpulan data biaya dan aplikasinya yang perlu ketelitian tinggi dapat terlaksana dengan mudah.

\section{Harga Pokok Produksi}

Harga pokok produksi atau products cost merupakan elemen penting untuk menilai keberhasilan (performance) dari perusahaan dagang maupun manufaktur. Harga pokok produksi mempunyai kaitan erat dengan indikator-indikator tentang sukses perusahaan, seperti misalnya: laba kotor penjualan, dan laba bersih (Mahdi Hendrich : 2013). Harga pokok produksi adalah jumlah dari seluruh pengorbanan sumber ekonomi yang digunakan untuk mengubah bahan baku menjadi produk. Perhitungan harga pokok produk dapat digunakan untuk menentukan harga jual yang akan diberikan kepada konsumen sesuai dengan biaya-biaya yang dikeluarkan dalam proses produksi.

\section{Variabel Costing}

Mulyadi (2012: 18) menyatakan bahwa "Metode variabel costing adalah metode penentuan kos produksi yang hanya memperhitungkan biaya produksi yang berperilaku variabel ke dalam kos produk, yang terdiri dari biaya bahan baku langsung, biaya tenaga kerja langsung, dan biaya overhead pabrik variabel.Variabel costing adalah metode penentuan harga pokok produksi yang hanya memperhitungkan biaya produksi yang berprilaku variabel ke dalam harga pokok produksi, yang terdiri dari biaya bahan bakulangsung, biaya tenaga kerja, dan biaya overhead pabrik variabel.

Beberapa anggota manajemen berpendapat bahwa metode variabel costing menyediakan data yang lebih mudah dipahami mengenai biaya, volume, pendapatan, dan laba kepada manajemen yang tidak ahli dalam teknik dan prosedur akuntansi. Metode variabel costing menyajikan data biaya dalam hubungannya dengan pendapatan dalam bentuk yang sederhana tanpa menyebabkan penyimpangan laba selama periode terjadinya fluktuasi produksi dan penjualan, karenavariabel cendrung berubah sesuai dengan penjualan.

Jika perusahaan menggunakan metode variabel costing, maka biaya tetap perlu dipisah menjadi biaya tetap langsung dan biaya tetap bersama. Biaya tetap langsung adalah biaya tetap yang menjadi bebanl angsung dimasing-masing segmen atau unit usaha. Sedangkan biaya tetap bersama adalah biaya tetap yang manfaatnya dinikmati secara bersama oleh semua segmen atau unit usaha.

\section{Biaya Semi Variabel}

Biaya semi variabel adalah biaya yang jumlah totalnya berubah sesuai dengan perubahan volume kegiatan, akan tetapi sifat-sifat perubahannya tidak sebanding. Semakin tinggi volume kegiatan semakin besar jumlah total biaya, semangkin rendah volume kegiatan semakin rendah pula jumlah total biaya, tetapi perubahannya tidak sebanding (not proportional).

Di dalam penyusunan anggaran variabel, pemisahan biaya semi variabel menjadi biaya tetap dan biaya variabel perlu dilakukan. Hal ini disebabkan karena anggaran variabel tersebut akan disusun untuk berbagai macam tingkat kapasitas yang dapat diselenggarakan di dalam perusahaan. Untuk kepentingan ini tentunya harus diketahui seberapa besarnya porsi biaya tetap dan seberapa besar porsi biaya variabel, sehingga perhitungan jumlah biaya untuk masing-masing tingkat kapasitas akan dapat dibuat dengan mudah.

\section{Penelitian Terdahulu}

Sitty Rahmi Lasena (2013) dengan judul penelitian : Analisis penentuan harga pokok produksi pada PT.Dimembe Nyiur Agripro. Penelitian ini bertujuan Untuk mengetahui perhitungan harga pokok produksi yang dilakukan oleh perusahaan. serta untuk membuat dan memperkenalkan penentuan harga pokok produksi dengan metode variabel costing pada perusahaan. Hasil penelitian ini menunjukan perusahaan menerapkan metode full costing dalam menghitung harga pokok produksi, hal ini dilihat dari dari penyajian unsur-unsur biaya produksi perusahaan yang tidak memisahkan antara biaya variabel dan biaya tetap. Adapun persamaan dari penelitian ini dengan yang dilakukan penulis yaitu menyangkut perhitungan harga pokok produksi. Perbedaan dari penelitian ini dengan yang diteliti penulis yaitu Kasus penelitian berbeda, objek Penelitian berbeda. 


\section{Jenis Penelitian}

\section{METODE PENELITIAN} kualitatif.

Jenis penelitian yang digunakan dalam penelitian ini adalah penelitian komparatif dengan pendekatan

\section{Tempat dan Waktu Penelitian}

Untuk memperoleh data yang dibutuhkan dalam penelitian ini, penulis mengadakan penelitian pada Aksan Bakery yang bertempat di Kelurahan Islam Lingkungan 1 Kecamatan Tuminting Kota Manado. Sedangkan jadwal penelitian ini dilaksanakan selama bulan April 2016.

\section{Prosedur Penelitian}

1. Menentukan judul dan merumuskan masalah.

2. Mengumpulkan data sesuai permasalahan yang diangkat.

3. Pengumpulan data melalui wawancara terhadap pihak-pihak yang terkait.

4. Mengelola data dan menginterpretasikan hasil pengolahan data.

5. Menarik kesimpulan dan memberikan saran.

\section{Metode Pengumpulan Data}

1. Jenis Data

Jenis data yang digunakan penulis dalam penelitian ini adalah data kualitatif yaitu data berbentuk informasi, baik dalam bentuk lisan maupun tulisan yang membantu dan mendukung data yang dibutuhkan misalnya berupa wawancara dengan pimpinan dan karyawan, dan data kuantitatif yaitu data berbentuk angka-angka yang masih perlu dianalisis kembali, misalnya: biaya bahan baku langsung, biaya tenaga kerja langsung, biaya overhead pabrik pada produksi roti pada Aksan Bakery.

2. Sumber Data
a. Data primer
b. Data Sekunder

Teknik Pengumpulan Data

1. Metode Wawancara

2. Metode Dokumentasi

3. Media Elektronik dan Media Buku

\section{Metode Analisis Data}

Metode analisis yang dipakai dalam penelitian ini adalah analisis deskriptif. penelitian desktriptif adalah suatu metode yang bertujuan untuk menggambarkan suatu keadaan perusahaan secara sistematis, aktual dan akurat dengan cara mengumpulkan data berdasarkan data yang nampak dalam perusahan, dimana fakta tersebut dikumpulkan, diolah, dan dianalisis sehingga selanjutnya dapat diambil suatu kesimpulan dan memberikan saran mengenai analisis harga pokok produksi pada Aksan Bakery di Manado.

\section{Teknik Analisis Data}

1. Analisis kegiatan produksi perusahaan yang menjadi objek penelitian guna memperoleh gambaran umum mengenai biaya-biaya yang terjadi dalam proses produksi.

2. Mengklasifikasi biaya-biaya menurut variabel costing

3. Menganalisa penentuan harga pokok produksi dengan menggunakan variabel costing.

4. Menarik kesimpulan

5. Memberikan saran.

\section{Hasil Penelitian}

\section{HASIL PENELITIAN DAN PEMBAHASAN}

Setiap harinya perusahaan memproduksi 3000 roti/harinya. Dalam menghitung harga pokok produksi Aksan Bakery menerapkan metode Full Costing, berikut data biayaroduksiAksan Bakery: 
Biaya Produksi Aksan BakeryTahun 2015

(Sebelum Pemisahan Biaya Variabel)

\begin{tabular}{|c|c|c|}
\hline \multirow{2}{*}{$\begin{array}{c}\text { Jenis } \\
\text { BiayaProduksi }\end{array}$} & \multicolumn{2}{|c|}{ Biaya Produksi } \\
\hline & (Rp) & $\begin{array}{c}\text { Per } \\
\text { Bungkus }\end{array}$ \\
\hline \multicolumn{3}{|l|}{ A. Biaya bahan baku langsung } \\
\hline 1. Tepung Terigu & 374.000 .000 & 400 \\
\hline 2. Ragi & 4.212 .000 & 4,5 \\
\hline 3. Telur & 47.424 .000 & 50,66 \\
\hline 4. Vanili & 4.368 .000 & 4,66 \\
\hline 5. Pewarna & 8.424 .000 & 9 \\
\hline 6. Pelembut & 270.000 & 0,288 \\
\hline 7. Pasta Pandan & 16.848 .000 & 18 \\
\hline 8. Mentega & 56.160 .000 & 60 \\
\hline 9. Coklat & 93.600 .000 & 100 \\
\hline 10. Keju & 17.550 .000 & 19 \\
\hline 11. Kacang & 17.550 .000 & 19 \\
\hline 12. GulaPasir & 93.600 .000 & 100 \\
\hline 13. Garam & 624.000 & 0,66 \\
\hline 14. GulaHalus & 17.082 .000 & 18,25 \\
\hline 15. SusuCair & 6.396 .000 & 6,83 \\
\hline 16. SusuBubuk & 11.700 .000 & 12,5 \\
\hline 17. Air & $\underline{1.716 .000}$ & $\underline{1,83}$ \\
\hline Jumlah Biaya Bahan Baku Langsung & $\underline{\underline{771.924 .000}}$ & $\underline{825,17}$ \\
\hline \multicolumn{3}{|l|}{ B. Biaya Tenaga Kerja Langsung } \\
\hline 1. Bagian pencampur & 28.800 .000 & 30,77 \\
\hline 2. Bagian pembentuk & 57.600 .000 & 61,54 \\
\hline 3. Bagian pemanggang & 26.400 .000 & 28,2 \\
\hline 4. Bagian pengemas & $\underline{26.400 .000}$ & 28,2 \\
\hline Jumlah Biaya Tenaga Kerja Langsung & $\underline{\underline{139.200 .000}}$ & $\underline{\underline{148,71}}$ \\
\hline \multicolumn{3}{|l|}{ C. Biaya Overhead Pabrik } \\
\hline 1. Biaya bahan penolong & 30.452 .000 & 32,53 \\
\hline 2. Biaya tenaga kerja tak langsung & 57.600 .000 & 61,53 \\
\hline 3. Biaya reparasi \& pemeliharaan & 29.900 .000 & 31,94 \\
\hline 4. Biaya listrik \& air & 12.000 .000 & 12,82 \\
\hline 5. Biaya bahan bakar & 78.880 .000 & 84,27 \\
\hline 6. Biaya makan & $\underline{72.000 .000}$ & $\underline{76,92}$ \\
\hline Jumlah Biaya Overhead Pabrik & $\underline{280.832 .000}$ & $\underline{300,03}$ \\
\hline Total Biaya Produksi $(\mathrm{A}+\mathrm{B}+\mathrm{C})$ & 1.191 .956 .000 & $1.273,45$ \\
\hline
\end{tabular}

Sumber: Aksan Bakery

Dari data biaya produksi di atas berikut perhitungan harga pokok produksi menurut Aksan Bakery: 


\section{Perhitungan Harga Pokok Produksi Aksan Bakery Tahun 2015}

\begin{tabular}{ll}
\hline Biaya Bahan Baku Langsung & 771.924 .000 \\
Biaya Tenaga Kerja Langsung & 139.200 .000 \\
Biaya Overhead Pabrik & $\underline{\underline{280.832 .000}}(+)$ \\
Harga Pokok Produksi & $\underline{\underline{1.191 .956 .000}}$
\end{tabular}

Sumber: Aksan Bakery

Harga pokok produksi per bungkus roti dapat dihitung dengan rumus:

$$
\begin{aligned}
& \text { Harga Pokok Produksi }=\operatorname{Rp} \frac{1.191 .956 .000}{936.000} \\
& \text { Perbungkus } \quad=\operatorname{Rp~1.273,45}
\end{aligned}
$$

\section{Pembahasan}

Salah satu faktor yang mempengaruhi meningkatnya laba operasional perusahaan adalah harga pokok produksi, dan dalam pembahasan ini ditekankan pada kalkulasi harga pokok produksi dengan metode variabel costing.

Metode Variabel costing merupakan suatu metode penentuan harga pokok produksi yang hanya memperhitungkan biaya produksi variabel saja atau yang berpengaruh langsung dengan hasil produksi. Berikut data biaya produksi Aksan Bakery dengan metode variabel costing yaitu sebagai berikut:

\section{Biaya Setelah Pemisahan Biaya Semi Variabel}

\begin{tabular}{|c|c|c|c|}
\hline \multirow{2}{*}{$\begin{array}{l}\text { Jenis } \\
\text { Biaya }\end{array}$} & \multicolumn{2}{|c|}{ Biaya } & \multirow{2}{*}{$\begin{array}{l}\text { Total } \\
\text { Biaya }\end{array}$} \\
\hline & Variable & Tetap & \\
\hline \multicolumn{4}{|l|}{ A. Biaya Bahan Baku Langsung } \\
\hline 1. Tepung Terigu & 374.400 .000 & - & 374.400 .000 \\
\hline 2. Ragi & 4.212 .000 & - & 4.212 .000 \\
\hline 3. Telur & 47.424 .000 & - & 47.424 .000 \\
\hline 4. Vanili & 4.368 .000 & - & 4.368 .000 \\
\hline 5. Pewarna & 8.424 .000 & - & 8.424 .000 \\
\hline 6. Pelembut & 270.000 & - & 270.000 \\
\hline 7. Pasta Pandan & 16.848 .000 & - & 16.848 .000 \\
\hline 8. Mentega & 56.160 .000 & - & 56.160 .000 \\
\hline 9. Coklat & 93.600 .000 & - & 93.600 .000 \\
\hline 10. Keju & 17.550 .000 & - & 17.550 .000 \\
\hline 11. Kacang & 17.550 .000 & - & 17.550 .000 \\
\hline 12. Gula Pasir & 93.600 .000 & - & 93.600 .000 \\
\hline 13. Garam & 624.000 & - & 624.000 \\
\hline 14. Gula Halus & 17.082 .000 & - & 17.082 .000 \\
\hline 15. Susu Cair & 6.396 .000 & - & 6.396 .000 \\
\hline 16. Susu Bubuk & 11.700 .000 & - & 11.700 .000 \\
\hline 17. Air & $\underline{1.716 .000}$ & - & $\underline{1.716 .000}$ \\
\hline Jumlah Biaya Bahan Baku Langsung & $\underline{\underline{771.924 .000}}$ & - & $\underline{\underline{771.924 .000}}$ \\
\hline
\end{tabular}
Aksan Bakery Tahun 2015 


\begin{tabular}{|c|c|c|c|}
\hline \multicolumn{4}{|l|}{ B. Biaya Tenaga Kerja Langsung } \\
\hline 1. Bagian Pencampur & 28.800 .000 & - & 28.800 .000 \\
\hline 2. Bagian Pembentuk & 57.600 .000 & - & 57.600 .000 \\
\hline 3. Bagian Pembakar & 26.400 .000 & - & 26.400 .000 \\
\hline 4. Bagian Pengemas & $\underline{26.400 .000}$ & - & $\underline{26.400 .000}$ \\
\hline Jumlah Biaya Tenaga Kerja Langsung & $\underline{\underline{139.200 .000}}$ & - & $\underline{\underline{139.200 .000}}$ \\
\hline \multicolumn{4}{|l|}{ C. Biaya Overhead Pabrik } \\
\hline 1. Biaya Bahan Penolong & 30.452 .000 & & 30.452 .000 \\
\hline 2. Biaya Tenaga Kerja Tak Langsung & - & 57.600 .000 & 57.600 .000 \\
\hline 3. Biaya Reparasi dan Pemeliharaan & 9.360 .000 & 20.540 .000 & 29.900 .000 \\
\hline 4. Biaya Listrik dan Air & 3.744 .000 & 8.256 .000 & 12.000 .000 \\
\hline 5. Biaya Bahan Bakar & 74.880 .000 & - & 74.880 .000 \\
\hline 6. Biaya makan karyawan & & 72.000 .000 & $\underline{72.000 .000}$ \\
\hline Jumlah Biaya Overhead Pabrik & $\underline{\underline{122.436 .000}}$ & $\underline{\underline{158.396 .000}}$ & $\underline{\underline{280.832 .000}}$ \\
\hline \multicolumn{4}{|l|}{ D. Biaya Operasional } \\
\hline 1. Gaji Bagian Adm/Umum & - & 24.000 .000 & 24.000 .000 \\
\hline 2. Biaya di Bank & - & 66.000 .000 & 66.000 .000 \\
\hline JumlahBiayaOperasional & - & $\underline{90.000 .000}$ & $\underline{90.000 .000}$ \\
\hline Jumlah Biaya $(\mathrm{A}+\mathrm{B}+\mathrm{C}+\mathrm{D})$ & $\underline{1.032 .652 .760}$ & 239.403 .240 & $\underline{1.272 .056 .000}$ \\
\hline
\end{tabular}

Sumber: Data Olahan

Dari data biaya produksi di atas berikut perhitungan harga pokok produksi menurut metode variable costing:

Perhitungan Harga Pokok Produksi dengan Metode Variabel CostingTahun 2015

\begin{tabular}{|c|c|}
\hline Biaya Bahan Baku Langsung & 771.924 .000 \\
\hline Biaya Tenaga Kerja Langsung & 139.200 .000 \\
\hline Biaya Overhead Pabrik Variabel & $\underline{122.436 .000}$ \\
\hline Harga Pokok Produksi Variabel & $\underline{\underline{1.033 .560 .000}}$ \\
\hline \multicolumn{2}{|c|}{$\begin{array}{l}\text { Sumber: Data Olahan } \\
\text { pokok produksi menurut metode Variabel Costing: } \\
\text { produksi }=\underline{1.033 .560 .000}\end{array}$} \\
\hline $\begin{array}{r}\frac{936.000}{}=1.104,23\end{array}$ & \\
\hline
\end{tabular}

\section{PENUTUP}

\section{Kesimpulan}

1. Aksan Bakery menerapkan metode full costing dalam menentukan harga pokok produksi, dimana dalam menghitung harga pokok produksi perusahaan membebankan semua unsur biaya produksi dengan berdasarkan biaya yang terjadi dalam proses produksi.

2. Berdasarkan perhitungan menurut variabel costing yang dibuat oleh penulis didapatkan hasil yang berbeda dengan perhitungan perusahaan yang menggunakan full costing. Perbedaan utama antara metode perhitungan full costing yang dipakai perusahaan dengan metode variabel costing terletak pada perlakuan biaya overhead pabrik. Dimana dalam metode full costing menggunakan biaya overhead tetap dan variabel, sedangkan metode dalam metode variabel costing hanya menggunakan biaya overhead variabel saja. 


\section{Saran}

Adapun saran-saran dari penulis untuk perusahaan, sehubungan dengan penelitian ini adalah sebagai berikut:

1. Sebaiknya perusahaan menggunakan metode variabel costing dalam menghitung harga pokok produksi. Karena dalam metode variabel costing dihitung semua biaya yang hanya berkaitan langsung dalam proses produksi.

2. Perlu adanya peningkatan efisiensi dalam penggunaan biaya produksi roti.

3. Perlu adanya biaya penyusutan aktiva tetap, guna menjadi biaya jaga-jaga untuk pabrik di masa yang akan datang

4. Sebaiknya perusahaan menambah tenaga kerja tak langsung khususnya dibagian pemasaran.

\section{DAFTAR PUSTAKA}

Badriyah, Huriariyah. 2015., "Buku Pintar Akuntansi Biaya Untuk Orang Awam”. HB, Jakarta

Hendrich, Mahdi (2013)., "Analisis Perhitungan Harga Pokok Produksi pada Usaha Peternakan Lele Pak Jay di Sukabangun II Palembang. Politeknik Darussalam”. Jurnal Ilmiah Vol.V No.3

Ikhsan, Arfan (2012)., "Pengantar praktis Akuntansi”. Edisi Kedua. Graha Ilmu. Yogyakarta

Jane, Bake (2010)., "Accounting Management by International Standars"., International Journal of Business and Management. 5(5), 36-43.

Lasena, Sity Rahmi (2013)., "Analisis Penentuan Harga Pokok Produksi pada PT. Dimembe Nyiur Agripro". Universitas Sam Ratulangi. Jurnal EMBA. Vol.1 No.3

Marwanto (2011)., "Analisis Perhitungan Variable Costing pada Ukiran Setia Katya Nanda Balikpapan". Politeknik Negeri Samarinda. Jurnal Eksis Vol.7 No.2

Mulyadi. (2012)., “Akuntansi Biaya”.Edisi Kelima. Unit penerbit dan percetakan Sekolah Tinggi Ilmu Manajemen YKPN, Yogyakarta.

Oentoe , Christy (2013)., "Analisis Perhitungan Biaya Produksi Menggunakan Metode Variable Costing". unsrat. Jurnal EMBA. Vol.1 No.3 